\title{
Finite Element Analysis of Orthogonal Cutting Forces in Machining AISI 1020 Steel by Using a Carbide Tip Tool

\author{
Bashistakumar M. ${ }^{1}$, Pushkal B. ${ }^{2^{*}}$
}

\begin{abstract}
${ }^{1}$ B. R. Ambedkar National Institute of Technology, Grand Trunk Road, Jalandhar, 144011 Punjab, India; ${ }^{2}$ L. Narain College of Technology, Kalchuri Nagar, Raisen Road, Bhopal, 462021 Madhya Pradesh, India

Article info:

Paper received:

The final version of the paper received:

Paper accepted online:

*Corresponding Author's Address:

pushkalb06@gmail.com

February 2, 2018

May 29, 2018

June 3, 2018

Abstract. Force modeling in metal cutting is important for various purposes, including thermal analysis, tool life estimation, chatter prediction, and tool condition monitoring. Numerous approaches have been proposed to model metal cutting forces with various degrees of success. In addition to the effect of work piece materials, cutting parameters, and process configurations, cutting tool thermal properties can also contribute to the level of cutting forces. The process of orthogonal metal cutting is studied with the finite element method under plane strain conditions. A numerical procedure has been developed for simulating orthogonal metal cutting using a general-purpose finite element method. The focus of the results presented in this work is on the effect of forces on the tool by variation of cutting parameters. The result is simulated with the analytical value for evolution of effective force for cutting material under various cutting condition.
\end{abstract}

Keywords: AISI 1020 steel, shaping, analytical model, finite element model, orthogonal cutting.

\section{Introduction}

Being the fundamental model for all cutting processes, modelling of the orthogonal cutting has been one of the most important problems for machining researchers for decades. Understanding the true mechanics and dynamics of the orthogonal cutting process would result in solution of major problems in machining such as parameter selection, accurate predictions of forces, stresses, and temperature distributions. In order to optimize machining processes three-dimensional models are indispensable that are capable to simulate three-dimensional chip flow using one cutting edge.

\section{Literature Review}

Both analytical and numerical methods have been used in the literature to model orthogonal cutting processes. The first successful mathematical attempt for understanding of the mechanics of orthogonal cutting is made by Merchant [1]. He studied the continuous type chips and formulated the deformation zone, i.e. the shear plane that is responsible for the formation of the chip by force equilibrium and the minimum energy principle. Although his work has several important assumptions, it is still widely used to understand the basics of the cutting process. Later, many researchers [2-7] worked on the modeling of the orthogonal cutting. After some deceleration in the research on cutting process mechanics due to the developments in CNC and CAD/CAM technologies, the process research regained some momentum in recent years. Many predictive models have been proposed by means of analytical, semi-analytical or completely numerical methods up to now. Semianalytical models, where some of the values are identified from the cutting tests, usually yield high prediction accuracy, however they may not always provide insight about the process [8-10]. In addition, the cutting tests can be time consuming depending on the number of variables and their ranges. Some analytical models may provide sufficient insight about the process and the solution times are usually very short. They can be grouped in some categories such as Johnson Cook material model [13], the slip-line models [15-19], and thin and thick shear zone models [20-22]. There are also several studies where the friction in machining is investigated. However, there are still issues in modeling the rake contact zone which involves the friction between the tool and the work piece due to the complex nature of the chip-tool contact. The objective of this study is to propose an orthogonal cutting model that integrates the primary 
and secondary deformation zones' effects on the cutting process. In modeling of the primary shear zone the study of Dudzinski and Molinari [21] is used. The model uses a thermo-mechanical constitutive relationship which is transformed to a Johnson-Cook type material model in this study. The shear plane is modeled having a constant thickness. In their later model, they modelled the friction on the rake face as a temperature dependent value. However, they just considered sliding contact conditions which may be valid for very high cutting speeds.

On the other hand, numerical models, such as FEM, [11-14] could provide much more detailed information about the process, such as temperature and pressure distribution on the rake face, however their accuracy is questionable and the solution times can be very long. A threedimensional FEM model was developed by Fang and Zeng [26] based on coupled thermo-elastic-plastic material flow. The model utilized a rigid tool and hence unable to simulate stresses inside the cutting tool. Cutting forces were measured at different inclination angles of the tool. The model was however, not validated experimentally. Zou et al. [27] made a new Orthogonal cutting model by using an upper bound approach. They introduced two new variables based on process kinematics that replaces chip flow angle and coefficient of friction in the traditional scheme. The chip flow angles predicted from the new model were found to be comparable with the experimental results. In numerical modeling methods, both finite difference methods (FDM) and finite element methods (FEM) have been used to model orthogonal cutting processes. An FDM model to predict temperature fields in orthogonal cutting was developed by Lazoglu and Islam [28]. The proposed a new method based on elliptical structural grid generation and the computational expense was found to be much less as compared to the conventional FE models. The temperature predictions were found to be in good agreement with the experimental data using the proposed finite difference method. Li and shih [29] developed a 3D finite element model (FEM) using AdvantEdge to simulate orthogonal turning of titanium. The model can predict cutting forces, temperature at the toolchip interface and chip thickness and the effect of various process parameters and cutting geometries can be investigated. In addition to continuous chip formation, serrated chips were also modeled. All the results are found to be in close agreement with the experimental observations. In addition to traditional Lagrangian scheme, Arbitrary Lagrangian Eulerian (ALE) method was also employed by researchers to model orthogonal cutting processes. An ALE model for orthogonal cutting of AISI 4340 with cemented carbide tools was developed by Llanos et al. [30]. Chip flow angles and cutting forces were predicted with different cutting parameters and tool geometries. Overall a good correlation was found with the experimental findings. The outputs of the proposed model are the cutting forces, the stress distributions on the rake face. Although the model is still under development, the final aim of the model is to develop a cutting process model which needs minimum amount of calibration tests. The friction and material constants can be obtained from or- thogonal cutting tests. After the calibration, the model can be applied for all machining operations using the same tool and work piece material.

This study aims to model orthogonal cutting process in shaping operations for AISI 1020 steel. Unlike ALE models which are computationally expensive, the developed model uses a Lagrangian approach technique. The model is able to predict initial chip formation, chip growth and steady state chip formation and does not need any prior assumption regarding the chip flow. The accuracy of the model is verified by comparing depth of cut, feed and radial forces with the analytical data. In addition tool performance and surface integrity of the work piece is analyzed using stress distribution in the work piece and the cutting tool.

\section{Research Methodology}

\subsection{Johnson-Cook material model}

The flow stress models that describe the work material behaviour as a function of temperature, strain and strain rate are considered highly necessary to represent work material constitutive behaviour under high-speed cutting conditions for work materials. Unfortunately sound theoretical models based on atomic level material behaviour are far from being materialized as reported by Jaspers and Dautzenberg [9]. Therefore, semi empirical constitutive models are widely utilized. Among such models, the constitutive model proposed by Johnson and Cook [13] describes the flow stress of a material with the product of strain, strain rate, and temperature effects that are individually determined as given in the following equation:

$$
\sigma_{A B}=\left[A+B\left(\bar{\varepsilon}_{A B}\right)^{n}\right]\left[1+c \ln \left(\frac{\dot{\dot{\varepsilon}_{A B}}}{\dot{\bar{\varepsilon}}_{0}}\right)\right]\left[1-\left(\frac{T-T_{0}}{T_{m}-T_{0}}\right)^{\mathrm{m}}\right]
$$

In the Johnson-Cook (JC) constitutive model, the parameter $A$ is the initial yield strength of the material at room temperature and a strain rate of $1 \mathrm{~s}^{-1}$ and $\bar{\varepsilon}$ represents the plastic equivalent strain. The equivalent plastic strain rate $\overline{\bar{\varepsilon}}_{A B}$ is normalized with a reference strain rate $\dot{\bar{\varepsilon}}_{A B}$. The temperature term in the JC model reduces the flow stress to zero at the melting temperature of the work material, $T_{m}$ leaving the constitutive model with no temperature effect. In general, the constants $A, B, C, n$, and $m$ of the model are fitted to the data obtained by several material tests conducted at low strains and strain rates and at room temperature as well as the split Hopkinson pressure bar (SHPB) tests at strain rates up to $10^{4} \mathrm{~s}^{-1}$ and at temperatures up to $600{ }^{\circ} \mathrm{C}[8,9]$.

The JC model provides a good fit for strain-hardening behavior of metals and it is numerically robust and can easily be used in FEM simulation models [13]. Zerilli and Armstrong (ZA) derived an alternative constitutive model for metals with a crystal structure distinction by using dislocation-mechanics theory [14]. 
The orthogonal cutting tests results for AISI 1020 are adopted from Oxley [6] that are performed for $0.2 \%$ carbon steel. The cutting conditions are given in Table 1. The flow stress data of SHPB tests adopted from Jasper and Dautzenberg [18] is combined with the flow stress determined under the orthogonal cutting conditions. The constants of the JC material model for work flow stress are computed as $A=333, B=737, C=0.008, n=0.15$, and $m=1.46$ for the extended ranges of strain $(0.051-1.070)$, strain-rate (1-17 $\left.766 \mathrm{~s}^{-1}\right)$ and temperature $\left(20-721^{\circ} \mathrm{C}\right)$.
Those constants are found in close agreements with the ones determined by Jasper and Dautzenberg [9], as given in Table 1, indicating the success of the proposed methodology.

The details of the computed process variables in the primary and secondary deformation zones are given in Table 2. The parameters of the tool-chip interface friction model are also computed by using the methodology proposed in this study as shown in Table 1 .

Table 1 - Material constants for the Johnson-Cook model obtained from SHPB tests [9]

\begin{tabular}{|l|c|c|c|c|c|c|c|}
\hline \multicolumn{1}{|c|}{ Material } & Reference & $\begin{array}{c}T_{m}, \\
{ }^{\circ} \mathrm{C}\end{array}$ & $\begin{array}{c}A, \\
\mathrm{MPa}\end{array}$ & $\begin{array}{c}B, \\
\mathrm{MPa}\end{array}$ & $c$ & $n$ & $M$ \\
\hline AISI 1045 & {$[9]$} & 1460 & 553.1 & 6000.8 & 0.0134 & 0.234 & 1.00 \\
\hline AISI 1020 & {$[9]$} & 1525 & 333.0 & 737.0 & 0.0080 & 0.150 & 1.46 \\
\hline AL 6082 T-6 & {$[9]$} & 582 & 428.5 & 327.7 & 0.0075 & 1.008 & 1.31 \\
\hline Ti6Al4V & {$[17]$} & 1630 & 862.5 & 331.2 & 0.0120 & 0.340 & 0.80 \\
\hline Ti6Al4V & {$[16]$} & 1630 & 782.7 & 498.4 & 0.0280 & 0.280 & 1.00 \\
\hline
\end{tabular}

Table 2 - Orthogonal test mild steel [9]

\begin{tabular}{|c|c|c|c|c|c|c|c|c|c|c|}
\hline $\begin{array}{c}V, \\
\mathrm{~m} / \mathrm{min}\end{array}$ & $\begin{array}{c}t_{1}, \\
\mathrm{~mm}\end{array}$ & $\begin{array}{c}t_{2}, \\
\mathrm{~mm}\end{array}$ & $\begin{array}{c}T_{A B}, \\
\mathrm{~s}\end{array}$ & $\begin{array}{c}T_{\text {int }}, \\
\mathrm{s}\end{array}$ & $K_{\text {chip }}$ & $\bar{\varepsilon}_{A B}$ & \& \& $_{A B}$ & $\bar{\varepsilon}_{\text {int }}$ & \& $\mathrm{E}$ int $^{\mathrm{E}}$ & $\begin{array}{c}\tau_{A B}, \\
\mathrm{~N} / \mathrm{mm}^{2}\end{array}$ \\
\hline 100 & 0.125 & 0.4 & 428 & 627 & 223.8 & 1.07 & 5488 & 1.55 & 1.50 & 558.5 \\
\hline 200 & 0.125 & 0.3 & 474 & 681 & 128.6 & 0.87 & 16488 & 1.28 & 5.35 & 648.6 \\
\hline 100 & 0.250 & 0.6 & 447 & 701 & 214.9 & 0.87 & 17766 & 1.28 & 10.70 & 579.5 \\
\hline 200 & 0.250 & 0.7 & 467 & 662 & 193.6 & 0.97 & 5861 & 1.42 & 0.98 & 579.3 \\
\hline 100 & 0.500 & 1.1 & 494 & 721 & 206.6 & 0.82 & 10632 & 1.21 & 3.18 & 624.4 \\
\hline 200 & 0.500 & 1.2 & 450 & 674 & 211.9 & 0.78 & 12653 & 1.14 & 7.70 & 614.0 \\
\hline 100 & 1.000 & 2.3 & 458 & 649 & 192.9 & 0.82 & 3399 & 1.21 & 0.79 & 634.0 \\
\hline 200 & 1.000 & 2.4 & 453 & 635 & 191.3 & 0.73 & 4814 & 1.07 & 2.37 & 647.0 \\
\hline
\end{tabular}

\subsection{The primary shear zone model}

The plastic deformation is assumed to take place only at the shear plane, and with plane strain conditions. Also the shear plane is modeled as a thin plane but having a thickness of $0.025 \mathrm{~mm}$. Moreover, the shear stress distribution at the outer boundary of the shear plane is assumed to be uniform. With the assistance of the equations of conversation of momentum and energy, and the constitutive law, Dudzinski and Molinari [21] proposed to solve a compatibility condition with an iterative procedure in order to calculate the shear stress at the entry of the shear plane, $\tau_{0}$. Moreover again from the equations of motion for a steady state solution and continuous type chip. The shear stress at the exit of the shear plane is calculated as presented in works $[21,22]$.

\subsection{Oxley's analysis of machining}

A simplified illustration of the plastic deformation for the formation of a continuous chip when machining a ductile material is given in Figure 1. There are two deformation zones in this simplified model a primary zone and a secondary zone. It is commonly recognized that the primary plastic deformation takes place in a finite-sized shear zone. The work material begins to deform when it enters the primary zone from lower boundary $C D$, and it continues to deform as until it passes the upper boundary $E F$. Oxley et al. [6] assumed that the primary zone is a parallel-sided shear zone.

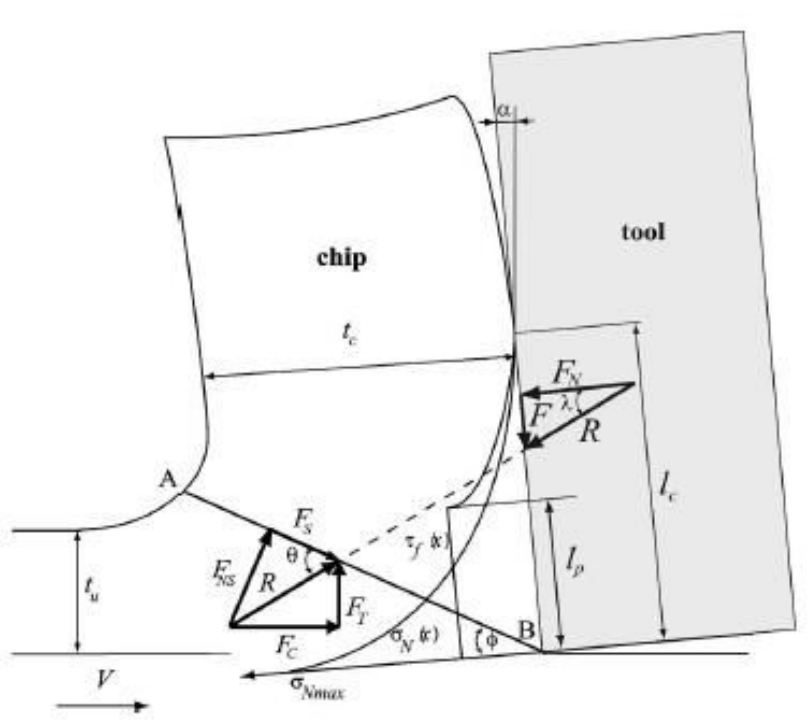

Figure 1 - Forces acting on the shear plane and the tool with resultant stress distribution on tool rake surface [6]

There is also a secondary deformation zone adjacent to the tool chip interface that is caused by the intense contact pressure and frictional force. After exiting from the primary deformation zone, some material experiences further plastic deformation in the 
secondary deformation zone. Using the quick-stop method to experimentally measure the flow field, Oxley [6] proposed a slip-line field similar to the one shown in Figure 1. Initially, Oxley and co-authors assumed that the secondary zone is a constant thickness shear zone. In this study, we assume that the secondary deformation zone is triangular shape and the maximum thickness is proportional to the chip thickness.

\subsection{Numerical experiment finite element modelling of shaper tool}

Numerical simulations with FEA were performed using the ABAQUS FE modeling software Advantage. Features to model machining processes in the software include adaptive remeshing capabilities for resolution of multiple length scales; multiple body deformable contact for tool-work interface, and transient thermal analysis. The material properties model contains deformation hardening, thermal softening and rate sensitivity associated with a transient heat conduction analysis for finite deformations. A constant coefficient of friction 0.2 is assumed in the simulations. The numerical simulations were performed with the commercial code ABAQUS/Explicit. The tool geometry and the cutting conditions are listed in Table 1. Two minor differences are: element layer of $2 \mu \mathrm{m}$ in the lagrangian mesh acting as an interface between the upper part of the work piece (which will be cut forming the chip) and the lower part of the work piece (which will be the machined surface) to minimize the losses of material due to erosion and allow separation assuming a von Mises type yield criterion and an isotropic strain hardening rule for the work piece material, the yield stress $\sigma_{y}$ is given by the Johnson-Cook equation.

The tool was assumed to behave as an elastic solid. Table 4 shows the detail properties of the work piece. Table 5 shows the mechanical parameters and Table 6 the thermal parameters of both material models. An element deletion criterion based on a critical value of the equivalent plastic strain was considered in the lagrangian mesh for the work piece material. This serves to erode the thin layer keeping the material at the chip. Previous work showed small influence of this criterion in cutting forces and temperature distribution, when critical value ranged from equivalent plastic strain 0.5 to 3.5 . No distortion was observed in the mesh with this criterion.

An initial temperature of $293 \mathrm{~K}$ was fixed for both solids. Although friction phenomena produce an intense heating at the tool-chip interface, friction .3 was considered as a first approximation to the problem. Numerical model was used to analyze influence of several parameters in model results (cutting forces and chip formation mainly).

Table 3 - The cutting condition and tool geometry used in Lagrangian approach

\begin{tabular}{|c|c|c|c|c|}
\hline $\begin{array}{c}\text { Clearance } \\
\text { angle }\end{array}$ & $\begin{array}{c}\text { Rake } \\
\text { angle }\end{array}$ & $\begin{array}{c}\text { Velocity, } \\
\mathrm{m} / \mathrm{min}\end{array}$ & $\begin{array}{c}\text { Depth of cut, } \\
\mathrm{mm}\end{array}$ & $\begin{array}{c}\text { Cutting } \\
\text { environment }\end{array}$ \\
\hline 0.5 & 0.10 & 100 & $0.5 ; 1.0$ & Dry \\
\hline
\end{tabular}

Table 4 - Workpiece properties of 1020 low carbon steel (mild steel)

\begin{tabular}{|l|l|l|}
\hline \multirow{5}{*}{ Minimum properties } & Ultimate tensile strength, Psi & 87000 \\
\cline { 2 - 3 } & Yield strength, Psi & 72000 \\
\cline { 2 - 3 } & Elongation & $10 \%$ \\
\cline { 2 - 3 } & Rockwell hardness & B89 \\
\hline \multirow{5}{*}{ Chemical composition } & Iron (Fe) & $99.08-99.53 \%$ \\
\cline { 2 - 3 } & Manganese (Mn) & $0.3-0.6 \%$ \\
\cline { 2 - 3 } & Carbon (C) & $0.18-0.23 \%$ \\
\cline { 2 - 3 } & Phosphorus (P) & $0.04 \% \max$ \\
\cline { 2 - 3 } & Sulphur (S) & $0.05 \% \max$ \\
\hline
\end{tabular}

Table 5 - Mechanical parameters of the workpiece and tool material models

\begin{tabular}{|l|c|c|c|c|c|c|c|c|c|c|}
\hline \multicolumn{1}{|c|}{ Material } & $\begin{array}{c}\rho, \\
\mathrm{kg} / \mathrm{m}^{3}\end{array}$ & $\begin{array}{c}E, \\
\mathrm{GPa}\end{array}$ & $v$ & $\begin{array}{c}A, \\
\mathrm{MPa}\end{array}$ & $\begin{array}{c}B, \\
\mathrm{MPa}\end{array}$ & $n$ & $c$ & $\varepsilon$ & $m$ & $B$ \\
\hline WP:AISI1020 mild steel & 7833 & 210 & 0.30 & 333 & 737 & 0.15 & 0.0080 & 1 & 1.46 & 0.9 \\
\hline Tool: CNMG 120404 (carbide tip) & 14500 & 450 & 0.19 & 896 & 656 & 0.50 & 0.0128 & - & 0.80 & - \\
\hline
\end{tabular}

Table 6 - Thermal parameter of the work piece and tool

\begin{tabular}{|l|c|c|}
\hline \multicolumn{1}{|c|}{ Material } & $\begin{array}{c}\text { Specific heat, } \\
\mathrm{J} /(\mathrm{kg} \cdot \mathrm{K})\end{array}$ & $\begin{array}{c}\text { Thermal conductivity, } \\
\mathrm{W} /(\mathrm{m} \cdot \mathrm{K})\end{array}$ \\
\hline WP:AISI1020 mild steel & 586 & 52.0 \\
\hline Tool: CNMG 120404 (carbide tip) & 234 & 33.5 \\
\hline
\end{tabular}




\section{Results and Discussion}

\subsection{Numerical simulation results}

Analytical approach to calculate cutting force, feed force and stress generation on the tool and work piece was calculated from taking the value from Tables $2-3$. The analytical calculation was considered for $100 \mathrm{~m} / \mathrm{s}$. For this velocity the different data were taken from previously conducting experiment that is Table 2 [9]. The chip thick- ness ratio and shear stress generated on the work piece were used to calculate shear angle, co-efficient of friction and cutting force generated on the work piece. Similarly Tables 1-2 used together to find out the stress generated on the chip during orthogonal cutting operation. The various models like JohnsonCook material model, Oxley's analysis of machining were used to find out the cutting force, feed force and stress generated in cutting process.

Table 7 - Analytical results

\begin{tabular}{|c|c|c|c|c|c|c|}
\hline \multirow{2}{*}{$\begin{array}{c}\text { Depth } \\
\text { of cut, } \\
\mathrm{mm}\end{array}$} & \multirow{2}{*}{$\begin{array}{c}\text { Clearance } \\
\text { angle }\end{array}$} & \multirow{2}{*}{$\begin{array}{l}\text { Rake } \\
\text { angle }\end{array}$} & \multicolumn{4}{|c|}{ Cutting forces and flow stress } \\
\hline & & & $F_{s}$ & $F_{c}$ & $F_{t}$ & $\sigma_{A B}, \mathrm{MPa}$ \\
\hline \multirow{4}{*}{0.5} & \multirow{2}{*}{0} & 0 & 195.1 & 299.8 & 55.01 & \multirow{4}{*}{704.7} \\
\hline & & 10 & 285.9 & 382.0 & 196.63 & \\
\hline & \multirow{2}{*}{5} & 0 & 195.1 & 299.8 & 55.01 & \\
\hline & & 10 & 285.9 & 382.0 & 196.63 & \\
\hline \multirow{4}{*}{1.0} & \multirow{2}{*}{0} & 0 & 416.1 & 659.8 & 175.55 & \multirow{4}{*}{755.1} \\
\hline & & 10 & 483.7 & 552.4 & 202.80 & \\
\hline & \multirow{2}{*}{5} & 0 & 416.1 & 659.8 & 175.55 & \\
\hline & & 10 & 483.7 & 552.4 & 202.80 & \\
\hline
\end{tabular}

In all the above cases depth of cut, clearance angle and rake angle are very according to requirement. When depth of cut increases cutting force and feed force value all so increases. The result of the cutting force and feed force directly depend upon the depth of cut and rake angle. The Johnson-Cook material model, primary shear zone model, Oxley's machining model, and analytical model were used to find out the result by using analytical equation. The clearance angle has no effect on calculating cutting forces. Its value remains same for same depth of cut and rake angle for whatever the clearance angle. The stress generated on tool chip interference remains same for individual depth of cut. The clearance and rake angle has no effect on the calculation of Stress generation. The resultant stress calculation was derived from Johnson-Cook material model equation and material parameters.

Finite element validation of cutting force, feed force and stress in machining of the AISI 1020 steel was addressed in present work. The finite element analysis is done by ABAQUS mechanical explicitly software. A work piece block was prepared with a dimension of $(50 \times 4 \times 15) \mathrm{mm}^{3}$. The material properties assignment was given from Johnson-Cook material model. A solid homogeneous section was assigned to the model. The proper meshing was done over the work piece model to evaluate good result. The meshing is here up to 12000 elements. The fix boundary condition was given to the model except the cutting zone. The same process maintained for the tool also.

The material properties for the tool were calculated from Johnson-Cook material model. Material section and meshing was also given to the tool model. In boundary condition tool movement direction was given, velocity $100 \mathrm{~m} / \mathrm{s}$ was maintained.

The different depth of cut maintained with different rake and clearance angle in this analysis. Detail analysis described below with graphical result.
For depth of cut $0.5 \mathrm{~mm}, 0^{\circ}$ clearance angle and $0^{\circ}$ rake angle, the maximum cutting force was found as $365 \mathrm{~N}$ at the starting point of the tool in $X$ direction and minimum force was $302 \mathrm{~N}$ at the end point of the tool. The maximum feed force in this analysis was $105 \mathrm{~N}$ at the starting point of the tool in $Y$ direction and minimum feed force was $38 \mathrm{~N}$ at the end point of the tool in the same direction. The maximum stress generated in this analysis was $8.5 \cdot 10^{8} \mathrm{~Pa}$ and minimum stress was $6.2 \cdot 10^{8} \mathrm{~Pa}$. The result of this analysis was given in Figures 3-6 in terms of graphical view.

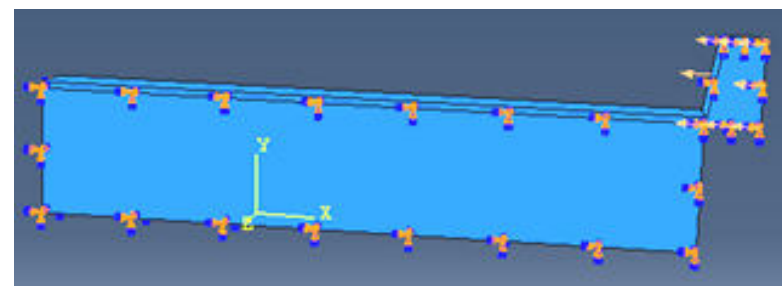

Figure 2 - Showing boundary conditions of tool and workpiece

For depth of cut $1.0 \mathrm{~mm}, 0^{\circ}$ clearance angle and $10^{\circ}$ rake angle, the maximum cutting force was found as $580 \mathrm{~N}$ at the starting point of the tool in $X$ direction and minimum force was $524 \mathrm{~N}$ at the end point of the tool. The maximum feed force in this analysis was $238 \mathrm{~N}$ at the starting point of the tool in $Y$ direction and minimum feed force was $176 \mathrm{~N}$ at the end point of the tool in the same direction. The maximum stress generated in this analysis was $8.1 \cdot 10^{8} \mathrm{~Pa}$ and minimum stress was $6.8 \cdot 10^{8} \mathrm{~Pa}$. The result of this analysis was given in Figures 7-10 in terms of graphical view.

The above process of finite element experiment was conducted for two different depths of cut 0.5 and $1.0 \mathrm{~mm}$, two different rake angles $0^{\circ}$ and $10^{\circ}$ and two different clearance angles $0^{\circ}$ and $5^{\circ}$. Likewise 8 experiments have been carried out to find out the result. The result table is given in Table 8 . 


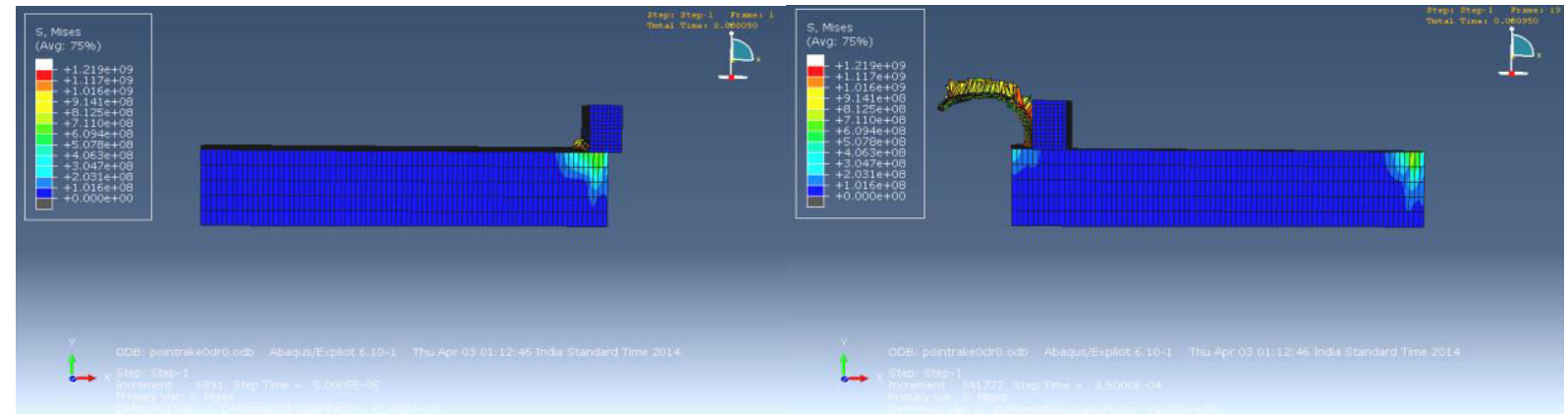

Figure 3 - Showing tool movement over work piece from start to end point for depth of cut $0.5 \mathrm{~mm}, 0^{\circ}$ clearance angle and $0^{\circ}$ rake angle
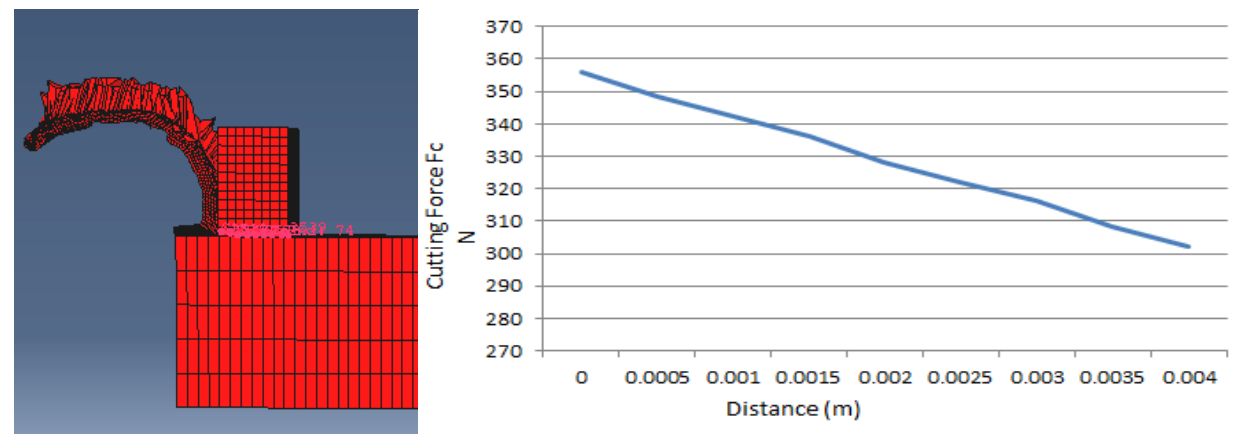

Figure 4 - Showing cutting force generated in $X$ direction for depth of cut $0.5 \mathrm{~mm}, 0^{\circ}$ clearance angle and $0^{\circ}$ rake angle
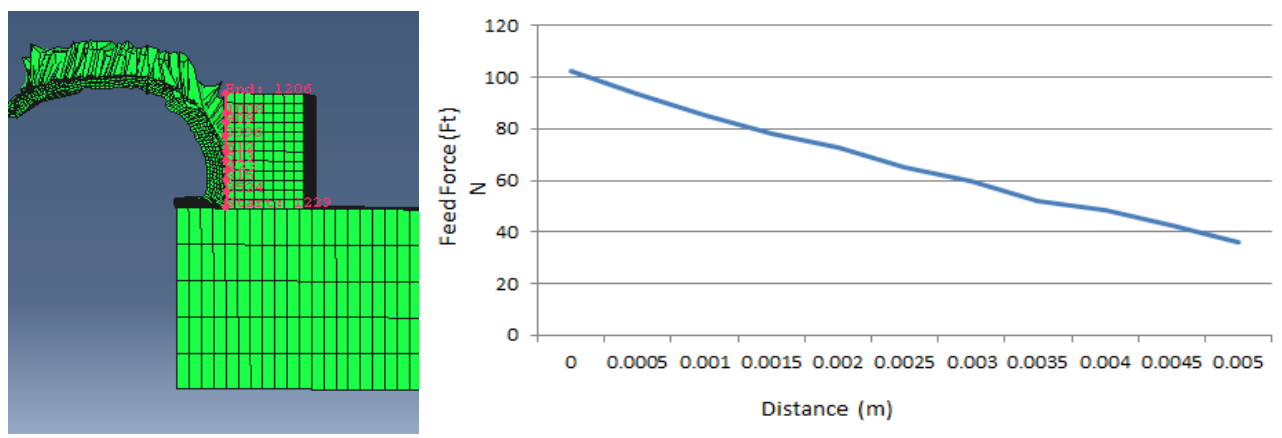

Figure 5 - Showing feed force generated in $Y$ direction for depth of cut $0.5 \mathrm{~mm}, 0^{\circ}$ clearance angle and $0^{\circ}$ rake angle
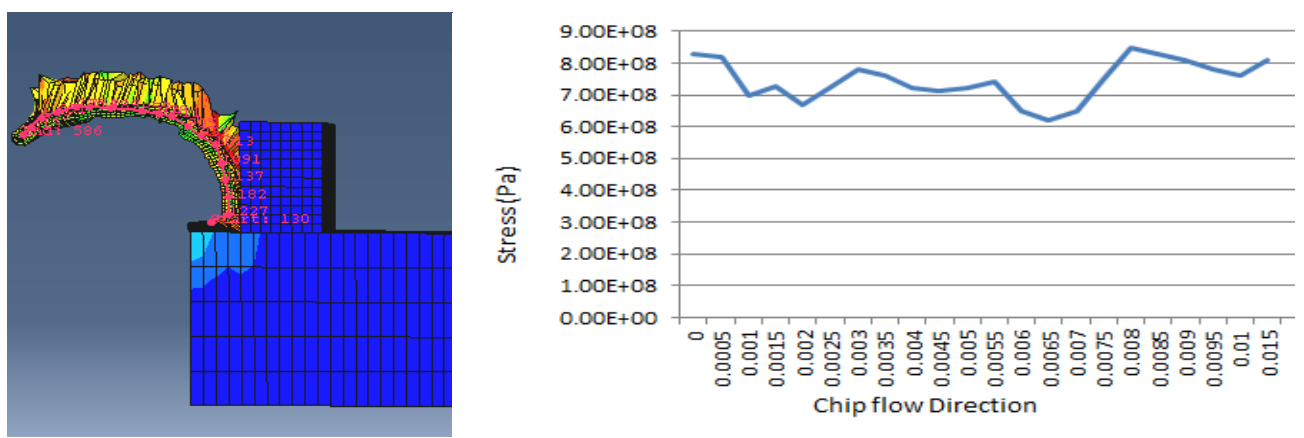

Figure 6 - Showing von Mises stress generated along chip flow direction for depth of cut $0.5 \mathrm{~mm}, 0^{\circ}$ clearance angle and $0^{\circ}$ rake angle 


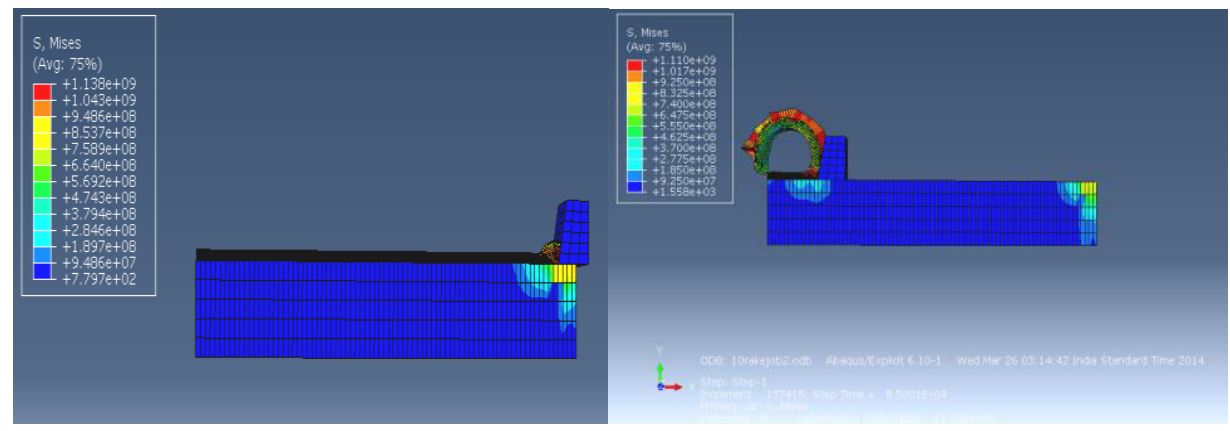

Figure 7 - Showing tool movement over work piece from start to end point for depth of cut $1.0 \mathrm{~mm}, 0^{\circ}$ clearance angle and $10^{\circ}$ rake angle
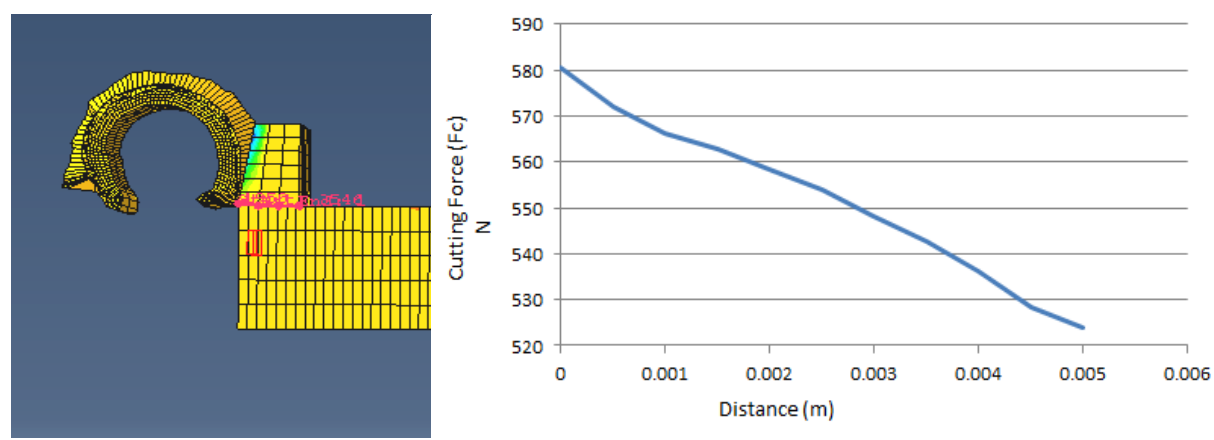

Figure 8 - Showing cutting force generated in $X$ direction for depth of cut $1.0 \mathrm{~mm}, 0^{\circ}$ clearance angle and $10^{\circ}$ rake angle
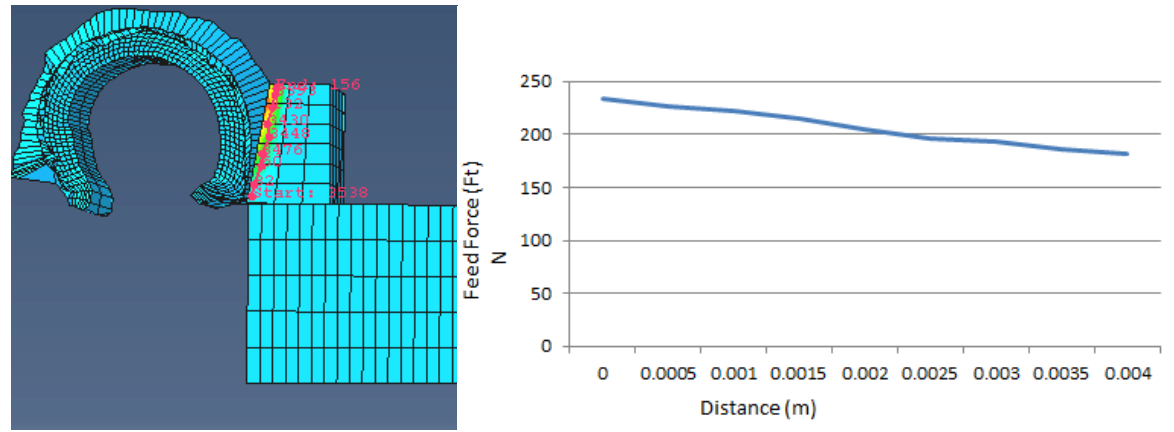

Figure 9 - Showing feed force generated in $Y$ direction for depth of cut $1.0 \mathrm{~mm}, 0^{\circ}$ clearance angle and $10^{\circ}$ rake angle
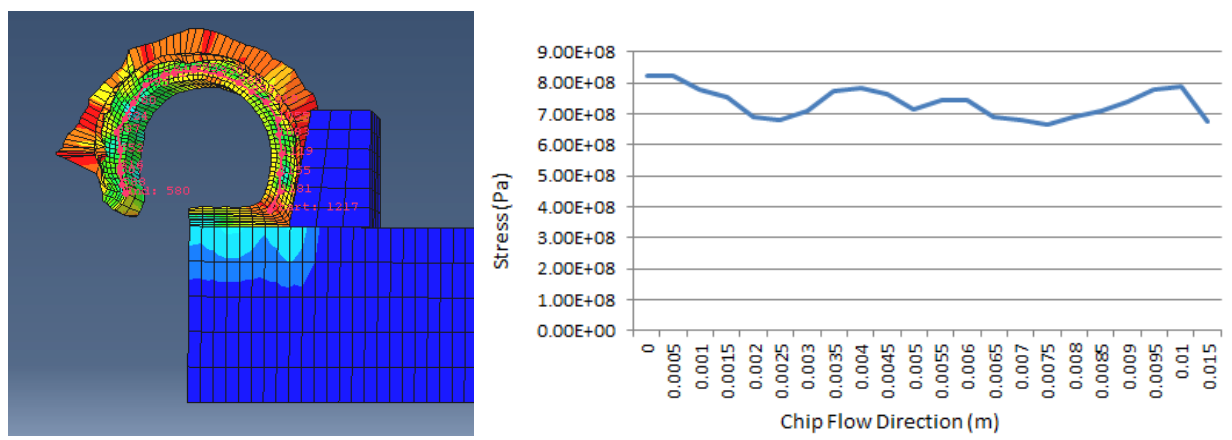

Figure 10 - Showing von Mises stress generated along chip flow direction for depth of cut $1.0 \mathrm{~mm}, 0^{\circ}$ clearance angle and $10^{\circ}$ rake angle 
Table 8 - Finite element analysis result

\begin{tabular}{|c|c|c|c|c|c|c|c|c|}
\hline \multirow[t]{2}{*}{$\begin{array}{l}\text { Depth } \\
\text { of cut, } \\
\text { mm }\end{array}$} & \multirow[t]{2}{*}{$\begin{array}{c}\text { Clearance } \\
\text { angle }\end{array}$} & \multirow[t]{2}{*}{$\begin{array}{l}\text { Rake } \\
\text { angle }\end{array}$} & \multicolumn{2}{|c|}{$\begin{array}{c}\text { Cutting } \\
\text { force } \\
F_{c}, \mathrm{~N} \\
\end{array}$} & \multicolumn{2}{|c|}{$\begin{array}{l}\text { Feed } \\
\text { force } \\
F_{t}, \mathrm{~N} \\
\end{array}$} & \multicolumn{2}{|c|}{$\begin{array}{c}\text { Stress } \sigma_{A B} \\
10^{8} \mathrm{~Pa}\end{array}$} \\
\hline & & & $\max$ & $\min$ & $\max$ & $\min$ & $\max$ & $\min$ \\
\hline \multirow{4}{*}{0.5} & \multirow{2}{*}{0} & 0 & 365 & 302 & 105 & 38 & 8.50 & 6.20 \\
\hline & & 10 & 450 & 382 & 238 & 170 & 8.20 & 6.50 \\
\hline & \multirow{2}{*}{. } & 0 & 318 & 279 & 85 & 38 & 8.40 & 4.50 \\
\hline & & 10 & 423 & 365 & 225 & 175 & 8.30 & 4.80 \\
\hline \multirow{4}{*}{1.0} & \multirow{2}{*}{0} & 0 & 691 & 622 & 200 & 152 & 8.53 & 6.32 \\
\hline & & 10 & 580 & 524 & 238 & 176 & 8.10 & 6.80 \\
\hline & \multirow{2}{*}{5} & 0 & 715 & 635 & 239 & 179 & 8.32 & 6.82 \\
\hline & & 10 & 614 & 539 & 220 & 175 & 8.51 & 4.90 \\
\hline
\end{tabular}

\subsection{Comparison of the results}

In this paragraph, a comparison between analytical results using the model reported in Table 8 and FE simulation presented in Table 9. The detail result was given below.

In this comparision the analytical rasult and the finite element result were not equal in any perticular point. The value of cutting force and feed force were maximum at the tool point or edge. The value were gradually decreases to wards the end point of the tool.
Stress generation on tool chip interference very with in the range of $(5.0-8.5) \cdot 10^{8} \mathrm{~Pa}$. From the graph it was clear that numerical approach (FEM) result for cutting force, feed force and stress generated on the tool chip interference is more than the analytical result. There was a varition of $20-100 \mathrm{~N}$ on feed force and cutting force by comparision of both the process. Stress generated on chip flow direction also very from point to point. By taking the maximum resultant case on each observation it was found that a diifference of $(0.5-1.0) \cdot 10^{8} \mathrm{~Pa}$ between both the process.

Table 9 - Comparisons between analytical result and finite element result

\begin{tabular}{|c|c|c|c|c|c|c|c|c|}
\hline \multirow{2}{*}{$\begin{array}{c}\text { Depth } \\
\text { of cut, } \\
\text { mm }\end{array}$} & \multirow{2}{*}{$\begin{array}{c}\text { Clearance } \\
\text { angle }\end{array}$} & \multirow{2}{*}{$\begin{array}{l}\text { Rake } \\
\text { angle }\end{array}$} & \multicolumn{3}{|c|}{ Analytical result } & \multicolumn{3}{|c|}{$\begin{array}{l}\text { Finite element analysis } \\
\text { result }\end{array}$} \\
\hline & & & $\begin{array}{c}F_{c}, \\
\mathrm{~N}\end{array}$ & $\begin{array}{c}F_{t}, \\
\mathrm{~N}\end{array}$ & $\begin{array}{c}\sigma_{A B} \\
10^{8} \mathrm{~Pa}\end{array}$ & $\begin{array}{c}F_{c 1}, \\
\mathrm{~N}\end{array}$ & $\begin{array}{c}F_{t 1}, \\
\mathrm{~N}\end{array}$ & $\begin{array}{l}\sigma_{A B 1}, \\
10^{8} \mathrm{~Pa}\end{array}$ \\
\hline \multirow{4}{*}{0.5} & \multirow{2}{*}{0} & 0 & 299.8 & 55.01 & 7.04 & 365 & 105 & 8.50 \\
\hline & & 10 & 382.3 & 196.63 & 7.04 & 450 & 238 & 8.20 \\
\hline & \multirow{2}{*}{5} & 0 & 299.8 & 55.01 & 7.04 & 318 & 85 & 8.40 \\
\hline & & 10 & 382.0 & 196.63 & 7.04 & 423 & 225 & 8.30 \\
\hline \multirow{4}{*}{1.0} & \multirow{2}{*}{0} & 0 & 659.8 & 175.55 & 7.55 & 691 & 208 & 8.53 \\
\hline & & 10 & 552.4 & 202.80 & 7.55 & 580 & 238 & 8.10 \\
\hline & \multirow{2}{*}{5} & 0 & 659.8 & 175.55 & 7.55 & 715 & 239 & 8.32 \\
\hline & & 10 & 552.4 & 202.80 & 7.55 & 614 & 220 & 8.51 \\
\hline
\end{tabular}

Reasons for significant difference in analytical and FEM model results:

1. Material parameters.

The material properties which are used to calculate analytical result for AISI 1020 steel is different from Johnson-Cook model material parameters. In FEM Johnson-Cook parameters with material properties are used to validate the FE experiment. These parameters are considered from previous experiment data. These are depend upon material flow rate, melting temperatue of material, properties of body and working condition.

2. Adiabatic heating.

Heat generated in the metal cutting can have a significant effect in the difference between the model result. The heat generation also directly affect the result of cutting forces and stress generation. The heat generation mechanism are the plastic work done in the primary and secondary shear zone and the sliding friction along the tool chip interference. In metal cutting process heat generated in the work piece and chip does not have sufficient time to diffuse away. Therefore temperature rise in work piece and chip is mainly due to localized adiabatic heating. Due to this reason also there is a significant difference between both the models.

\section{Separation criterion.}

This criterion states that chip separation occur when the stress along the cutting path reach a critical combination at a specified distance in front of the tool tip. To implement this criterion in ABAQUS the cutting path in work piece is defined by contact surface. Paired finite element nodes on the contact surface are initially in the perfect bond. When the chip separation criterion is met at the specified 
distance in front of the tool tip, the pair of finite elements above and below the contact surface immediately before the tool tip will separate thus this process also partially affect the difference between the model results.

4. Friction generation.

Friction plays a very important role in metal cutting. It not only determine the power requirement for removing a given volume of metal but also controls the surface quality of the finish product and the rate of wear of cutting tool. Friction is also difficult to model in the metal cutting. In analytical model friction is solely depends upon the frictional angle ' $\beta$ ' and frictional angle depend upon chip thickness ratio. Chip thickness ratio already determined from experimental data. For a particular cutting, a frictional angle is fixed. So for a particular operation a particular result is developed. The friction is depend upon the rake angle and clearance angle which are used in the operation. So the resultant forces and stress generation inanalytical process solely depend upon the friction coefficient, rake angle and clearance angle which are used in the analytical model equation to find out the result. On the other hand in FEM simulation by ABAQUS friction is taken as a constant from $0.2-0.9$ which is vary from material to material. In this case I have used frictional constant as 0.3. During material cutting operation basically friction changes time to time due to material behaviour in cutting zone. Therefore frictional constant also affect the cutting forces for finding out the result.

\section{Conclusions}

The proposed finite element model can be used quite satisfactorily to predict cutting forces, Stresses and chip morphology to a reasonable degree of accuracy.

Rake angle effect in orthogonal cutting can be simulated using the developed FEM model.

Depth of cut has the largest effect on the cutting forces, whereas clearance angle has no significance influence in cutting process.

The stress and force field predicted by the FE model are in accordance with the experimental findings and theoretical knowledge.

Chip flow can easily be predicted by observing the direct stress contour at the rake face of the tool.

\section{References}

1. Ernst, H., \& Merchant, M. E. (1941). Chip Formation, Friction and High Quality Machined Surfaces. Trans. Am. Soc. Met., Vol. 29, pp. 299-378.

2. Lee, E. H., \& Shaffer, B. W. (1951). The Theory of Plasticity Applied to a Problem of Machining. J. Appl. Mech., Vol. 18, pp. 405-413.

3. Zorev, N. N. (1963). Inter-Relationship Between Shear Processes Occurring Along Tool Face and Shear Plane in Metal Cutting. International Research in Production Engineering, ASME, New York, pp. 42-49.

4. Tay, A. O., Stevenson, M. G., \& de Vahl Davis, M. G. (1974). Using the Finite Element Method to Determine Temperature Distributions in Orthogonal Machining. Proceedings of the Institution for Mechanical Engineers, Vol. 188, pp. 627-638.

5. Usui, E., \& Shirakashi, T. (1982). Mechanics of Machining: From Descriptive to Predictive Theory. On the Art of Cutting Metals - 75 Years Later, ASME, New York, PED 7, pp. 13-35.

6. Oxley, P. L. B. (1989). Mechanics of Machining, an Analytical Approach to Assessing Machinability. Ellis Horwood Ltd.

7. Özel, T., \& Altan, T. (2000). Determination of Workpiece Flow Stress and Friction at the Chip-Tool Contact for High-Speed Cutting. Int. J. Mach. Tools Manuf., Vol. 40/1, pp. 133-152.

8. Childs, T. H. C. (1998). Material Property Needs in Modeling Metal Machining. Proceedings of the CIRP International Workshop on Modeling of Machining Operations, Atlanta, Georgia, May 19, pp. 193-202.

9. Jaspers, S. P. F. C., \& Dautzenberg, J. H. (2002). Material Behavior in Conditions Similar to Metal Cutting: Flow Stress in the Primary Shear Zone. J. Mater. Process. Technol., Vol. 122, pp. 322-330.

10. Adibi-Sedeh, A. H., Madhavan, V., \& Bahr, B. (2003). Extension of Oxley's Analysis of Machining to Use Different Material Models. ASME J. Manuf. Sci. Eng., Vol. 125, pp. 656-666.

11. Davies, M. A., Cao, Q., Cooke, A. L., \& Ivester, R. (2003). On the Measurement and Prediction of Temperature Fields in Machining 1045 Steel. CIRP Ann., Vol. 52 (1), pp. 77-80.

12. Özel, T., \& Altan, T. (2000). Process Simulation Using the Finite Element Method: Prediction of Cutting Forces, Tool Stresses and Temperatures in High-Speed Flat End Milling Process. Int. J. Mach. Tools Manuf., Vol. 40/5, pp. 713-738.

13. Johnson, G. R., \& Cook, W. H. (1983). A Constitutive Model and Data for Metals Subjected to Large Strains, High Strain Rates and High Temperatures. Proceedings of the 7th International Symposium on Ballistics, Hague, Netherlands, pp. 541-547.

14. Zerilli, F. J., \& Armstrong, R. W. (1987). Dislocation-Mechanics-Based Constitutive Relations for Material Dynamics Calculations. J. Appl. Phys., Vol. 61 (5), pp. 1816-1825.

15. Hamann, J. C., Grolleau, V., \& Le Maitre, F. (1996). Machinability Improvement of Steels at High Cutting Speeds - Study of Tool/Work Material Interaction. CIRP Ann., Vol. 45, pp. 87-92.

16. Lee, W. S., \& Lin, C. F. (1998). High-Temperature Deformation Behavior of Ti6AL4V Alloy Evaluated by High Strain-Rate Compression Tests. J. Mater. Process. Technol., Vol. 75, pp. 127-136.

17. Meyer Jr, H. W., \& Kleponis, D. S. (2001). Modeling the High Strain Rate Behavior of Titanium Undergoing Ballistic Impact and Penetration. Int. J. Impact Eng., Vol. 26, pp. 509-521. 
18. Shatla, M., Kerk, C., \& Altan, T. (2001). Process Modeling in Machining. Part I: Determination of Flow Stress Data. Int. J. Mach. Tools Manuf., Vol. 41, pp. 1511-1534.

19. Tounsi, N., Vincenti, J., Otho, A., \& Elbestawi, M. A. (2002). From the Basic Mechanics of Orthogonal Metal Cutting toward the Identification of the Constitutive Equation. Int. J. Mach. Tools Manuf., Vol. 42, pp. 1373-1383.

20. Adibi-Sedeh, A. H., \& Madhavan, V. (2002). Effect of Some Modifications to Oxley's Machining Theory and the Applicability of Different Material Models. Mach. Sci. Technol., Vol. 6 (3), pp. 379-395.

21. Lee, L. C., Liu, X., \& Lam, K. Y. (1995). Determination of Rake Stress Distribution in Orthogonal Machining. Int. J. Mach. Tools Manuf., Vol. 35 (3), pp. 373-382.

22. Huang, Y., \& Liang, S. Y. (2003). Cutting Forces Modeling Considering the Effect of Tool Thermal Property-Application to CBN Hard Turning. Int. J. Mach. Tools Manuf., Vol. 43, pp. 307-315.

23. Moufki, A., Devillez, A., Dudzinski, D., \& Molinari, A. (2004). Thermomechanical modelling of oblique cutting and experimental validation. International Journal of Machine Tools and Manufacture, No. 44:971.

24. Molinari, A., \& Moufki, A. (2005). A new thermomechanical model of cutting applied to turning operations. Part I. Theory. International Journal of Machine Tools and Manufacture, Paper no. 45:166.

25. Moufki, A., \& Molinari, A. (2005). A new thermomechanical model of cutting applied to turning operations. Part II. Parametric study. International Journal of Machine Tools and Manufacture, Paper no. 45:181.

26. Fang, G., \& Zeng, P. (2005). Three-dimensional thermo-elastic-plastic coupled FEM simulations for metal orthogonal cutting processes. Journal of Materials Processing Technology, Paper no. 168:42.

27. Zou, G. P., Yellowley, I., \& Seethaler, R. J. (2009). A new approach to the modeling of orthogonal cutting processes. International Journal of Machine Tools and Manufacture, Paper no. 49:701.

28. Lazoglu, I., \& Islam, C. (2012). Modeling of 3D temperature fields for oblique machining. CIRP Annals - Manufacturing Technology, Paper no. 61:127.

29. Li, R., \& Shih, A. J. (2006). Finite element modeling of 3D turning of titanium. The International Journal of Advanced Manufacturing Technology, Paper no. 29:253.

30. Llanos, I., Villar, J. A., Urresti, I., \& Arrazola, P. J. (2009). Finite element modeling of oblique machining using an arbitrary Lagrangian-Eulerian formulation. Machining Science and Technology, Paper no. 13:385.

\title{
Скінченноелементний аналіз ортогональних сил різання при обробці сталі AISI 1020 з використанням твердосплавного різального інструменту
}

\author{
Башистакумар М. ${ }^{1}$, Пушкал Б. ${ }^{2}$
}

${ }^{1}$ Національний технологічний інститут ім. Б. Р. Амбедкара, Гранд Транк роуд, 144011, м. Пенджаб, Індія;
${ }^{2}$ Технологічний коледж ім. Л. Нараяна, Райзен роуд, 62021, м. Мандх’я Парадеш, Індія

\begin{abstract}
Анотація. Моделювання сил різанні металу має важливе значення для різних цілей, включаючи термічний аналіз, оцінку ресурсу інструменту, прогнозування ресурсу і моніторинг стану інструменту. Запропоновано числові методи моделювання сил різання металевих заготовок. Додатково встановлені параметри процесу різання деталей, що обробляються, теплові властивості різального інструменту. Процес ортогонального різання металу досліджується методом скінченних елементів за умов плоскої деформації. Розроблена числова процедура, що реалізує метод скінченних елементів для моделювання ортогонального різання сталей загального призначення. Основна увага приділена результатам щодо впливу сил різання на інструмент при зміні параметрів різання. Результати визначаються як аналітично так і числовими методами для заданої сили різання матеріалу з різними параметрами процесу.
\end{abstract}

Ключові слова: сталь AISI 1020, формування, аналітична модель, скінченноелементна модель, ортогональне різання. 